\title{
Missing in Action: Strategic Human Resource Management in German Nonprofits.
}

\author{
Marlene Walk \\ University of Pennsylvania \\ School of Social Policy and Practice \\ 3701 Locust Walk, Philadelphia, PA-19104 \\ Email: marlwalk@sp2.upenn.edu \\ Phone: +1-215 5432748 \\ Heike Schinnenburg \\ University of Applied Sciences Osnabrück \\ Faculty of Business Management and Social Sciences \\ Caprivistrasse $30 \mathrm{~A}$ \\ D-49076 Osnabrück \\ Email: schinnenburg@wi.hs-osnabrueck.de \\ Phone: +49-5419693643 \\ Femida Handy \\ University of Pennsylvania \\ School of Social Policy and Practice \\ 3701 Locust Walk, Philadelphia, PA-19104 \\ Email: fhandy@sp2.upenn.edu \\ Phone: +1-215 5732660
}

Manuscript as accepted by Voluntas: International Journal of Voluntary and Nonprofit Organizations.

The final publication is available at link.springer.com.

Citation: Walk, M.; Schinnenburg, H.; Handy, F. (2014): Missing in Action: Strategic Human Resource Management in German Nonprofits. Voluntas: International Journal of Voluntary and Nonprofit Organizations, 25(4), 9911021. DOI $10.1007 / \mathrm{s} 11266-013-9380-7$ 


\section{Introduction}

Human service nonprofits provide labor-intensive services and, as such, employees are a major factor in determining organizational success (Maelicke, 2004). Thus, nonprofits involved in human services are highly dependent on the quality, motivation, and satisfaction of their employees for the delivery of their services (Akingbola, 2006). Job satisfaction is influenced by many endogenous factors at the workplace, such as relations with co-workers, supervisors, and clients (Borzaga \& Depedri, 2005; Ducharme, Knudsen, \& Roman, 2008; Ewald, 1997), professional development possibilities (Borzaga \& Tortia, 2006), and compensation and appropriateness of wages (Glisson \& Durick, 1988). Other, often underrated factors in employees' job satisfaction is their perception of human resource (HR) practices (Nishii, Lepak, \& Schneider, 2008) and their evaluation of the extent to which the job fulfills their own needs and values (Locke, 1976).

Research shows that the way an organization manages its human resources significantly influences organizational performance (Khilji \& Wang, 2006; Ostroff, 1992; Pfeffer, 2007). Given the competitive climate in human services, it is increasingly important for nonprofits to understand their employees' perceptions of their organization's HR practices in order to implement a human resource management (HRM) that best fulfill the needs of the organization and its workforce.

Even though the theoretical link between performance and employee perceptions of HR practices may be clear (Kuvaas, 2008; Truss, 2001), in practice however, organizations often either lack information on their employees' perceptions or do not incorporate this information in their HR practices (Nishii et al., 2008). This is especially true for nonprofit organizations, where little is known about how employees perceive and evaluate HR practices. Theoretically the question remains, what discourages nonprofit organizations from implementing HR practices that create job satisfaction and commitment to the organization? Are there internal or external barriers in implementing such HR practices? Are the employee perceptions of HR practices in an organization shared by HR managers? Is there a gap between the realities of what is feasible with what is desirable in effective HR practices?

This research focuses on HR practices as perceived by employees and HR managers in free welfare associations (FWAs) in Germany, the main provider of social and health care services (Zimmer et al., 2004). 
Our aim is to understand what impedes the implementation of HR practices in FWAs that could potentially improve recruitment and retention, and increase job satisfaction. Thus, we examine what is 'missing in action' in understanding the interplay of how managers and employees perceive HR practices and the barriers for implementing strategic HR practices. This line of inquiry will add to the current knowledge base on strategic human resource management (SHRM) research on nonprofits, an area where empirical data is widely missing (Guo, Brown, Ashcraft, Yoshioka, \& Dong, 2011).

\section{Context: Human Resource Practices in German FWAs}

This paper focuses on free welfare associations (FWAs), the main provider of social services and health care in Germany (Zimmer et al., 2004). Typical services that FWAs provide include day care centers, child and youth welfare services, health services, unemployment consulting, assistance to immigrants, and elderly care. Given the broad spectrum of clients and purposes FWAs serve, it is not surprising that the workforce is heterogeneous and the typical professions found among professional employees are social work, nursing, and education (Burmester, 2005; Neumann, 2004). FWAs also offer a variety of employment options, with a diverse overall structure as seen in Table 1. Significant variations in staff professionalization, duration of employment, incentives, contract characteristics, as well as the handling of labor laws, regulations and tax implications, especially for subsidized jobs, pose extraordinary challenges for HRM (Vilain, 2002; Zimmer \& Freise, 2003).

\section{- INSERT TABLE 1 ABOUT HERE -}

Due to the historical foundations of FWAs, there existed heavily bureaucratic structures with a general lack of flexibility and a management style that has been described as passive rather than pro-active and strategic (Zimmer \& Toepler, 2000). Having enjoyed a monopoly in the delivery of many human services as well as guaranteed funding, FWAs found themselves severely challenged when the government changed its policy in the 1990s consequent to the Youth Welfare Act of 1991 and the Health Care Reconstruction Act of 1993 (Zimmer \& Toepler, 2000). Reduced government funding was accompanied by a competitive landscape as the government opened up the provision of human services and health care to other vendors, including for-profit and other nonprofit organizations. Thus, FWAs faced rising demands from government for 
increased quality in services with concomitant reduction in costs (Buestrich, Finke-Oltmann, \& Wohlfahrt, 2008) and found themselves exposed to marketplace risks hitherto not encountered (Marcus, 2008).

Furthermore, due to changes in demographics, FWAs faced an increased demand of their services from a rapidly aging client population with changing needs (Ridder, Bruns, \& Neumann, 2004). Simultaneously, FWAs experienced a shortage of skilled labor for the provision of their services (Wohlfahrt, 2012) as there were fewer younger people who were choosing caring professions (Brinkmann, 2008).

To navigate these changes and compete in the market place, many FWAs responded by imitating the management systems of their competing for-profit sector organizations, often without sufficiently adapting them to their own or their employees' needs or developing new systems that would serve them better (Neumann, 2004; Vilain, 2002). For example, one measure was to apply a cost-saving strategy by increasing the number of part-time employees. Part-time employees enjoy fewer benefits and lower compensation than full-time employees, therefore FWAs were able to save on personnel costs (Neumann, 2004). Between 2000 and 2008, the share of full-time employees decreased from 60 percent in 2000 to 44 percent in 2008, while the total number of employees increased by 32 percent to 1.5 million employees (BAGFW e.V., 2000, 2006, 2008). Similarly, Wohlfahrt (2012) finds that during the past decade, FWAs have increased the share of lowqualified personnel, who were subsidized by the government, thereby allowing FWAs to save on wage costs. Unfortunately, HR practices did not change sufficiently to accommodate this changing workforce composition, leading to dissatisfaction among employees (Brinkmann, 2008) and little research exists on the resulting challenges faced by FWAs and their HR responses to the changes in their environment.

In the next section, we summarize the relevant literature on the four most prominent HR practices of recruitment, appraisal, development, and compensation (Devanna, Fombrun, \& Tichy, 1984) as they relate to FWAs.

Recruitment: Organizations that want to hire the most qualified people for the job must design a recruitment plan that supports the organizational strategy (Delaney \& Huselid, 1996). However, in the past, FWAs paid little attention to staff recruitment due to their monopolistic position. Furthermore, the supply of job applicants exceeded demand due to the high numbers of graduates in the field of social work, education, 
and health care (Neumann, 2004). Recruitment often occurred informally; affiliations to particular political parties or religious groups or personal connections were hereby highly valued and parlayed into jobs in FWAs (Betzelt, 2001; Hüdepohl, 1996; Wöhrle, 2008). Betzelt (2001) finds that subject-specific qualifications were not necessarily criteria for getting hired, but being "from the same stable" (p. 159), i.e. belonging to the same networks as existing staff, was a precondition for employment. Even though FWAs started to use more formal procedures of staff recruitment (e.g. job advertisement) in the past few years, these efforts appear to be mostly ad hoc. Often, internal applicants get preference, which causes redeployment in other areas and restricts the search for good candidates (Betzelt, 2001; Neumann, 2004; Zimmer \& Freise, 2003).

Due to the low public image of social services in German society coupled with low compensation and poor working conditions in FWAs (Neumann, 2004; Oliva, Oppl, \& Schmid, 1991), there is now a shortage in the supply of skilled personnel (Vilain, 2002; Wohlfahrt, 2012). Recent statistics estimate that the areas of child and youth welfare services, elderly care, and nursing are especially affected by this lack of skilled personnel. For instance, by 2014 there will be a need for 110,000 child welfare employees; 45\% of it will be due to retirements and remaining due to the expansion of services (e.g. daycare). Similarly there will be increased needs in nursing; especially in elder care due to the aging of the population and the increased life expectancy, a threefold increase $(1,600,000)$ is predicted (Thole, 2011).

Furthermore, because of increasing competition for qualified employees with for-profit providers, the pool of available applicants to FWAs is low. However, FWAs rarely act upon these changes in their recruitment and selection practices (Buestrich et al., 2008; Wohlfahrt, 2012). Thus, FWAs are left "with a permanent deficit of qualified staff' (Vilain, 2002, p. 10).

Compensation: Most FWAs pay their employees according to a collective agreement (TVÖD), implemented in 2005 as a result of the changes in public funding. This agreement allows increases in pay according to an employee's tenure within FWAs (Vilain, 2002). While such wages may be effective in certain industries, it is questionable whether they would attract better employees as some recent research findings show that young employees in FWAs prefer that their work and efforts are valued with monetary incentives such as performance-based benefits (Walk, Handy, \& Schinnenburg, 2013). 
Although performance-based payments gained attention in recent nonprofit literature (e.g. Theuvsen, 2004), there is some ambiguity about its merit due to its effects on crowding out intrinsic motivations over time (Deckop \& Cirka, 2000). FWAs have not had a culture of performance-based payments, although payfor-performance plans have been discussed for a while (EKD, 2002; Knorr \& Scheppach, 1998) and have recently been implemented in Protestant FWAs (VdDD, 2013). Given their reliance on short-term projectbased contracts, it has been difficult for FWAs to integrate performance related pay schemes that are sustainable across their workforce (Dahme \& Wohlfahrt, 2007). Thus, FWAs often rely on the length of tenure in determining wages, which corresponds to lower salaries for entry-level professional employees that are not in line with their professional education ${ }^{1}$. Not surprisingly, this policy is perceived as unfair and caused significant dissatisfaction among entry level employees (Walk et al., 2013).

Appraisal: Employee appraisal is an effective tool to discuss professional development goals such as training or education (Deckop \& Cirka, 2000), and FWAs indeed use employee appraisal for professional development of employees, the improvement and maintenance of personnel quality, and increases in overall efficiency (Strassner, 2009). Appraisal talks allow FWA supervisors to work with their employees on their strengths and weaknesses and thus, are part of their personnel responsibilities; they also give employees the opportunity to influence their job design (Hesse, 2006). However, appraisal talks are not uniformly or widely implemented, and when conducted, there exist significant differences in terms of regularity and substance across the different FWAs (Göpfert-Divivier \& Ahr, 2004). For instance, in some FWAs, supervisors initiate appraisal talks, whereas in others, the employees take the initiative; the frequency and regularity differ, as do the nature and length of the talks (Hesse, 2006; Marcus, 2008). Furthermore, Strassner (2009) points to ethical issues that arise in appraisal talks that lead to "strategic dishonesty" (p. 48), especially for employees who are in vulnerable situations (e.g. on temporary contracts with an uncertainty of renewal).

Professional Development: Professional development efforts have positive individual-level as well as organizational effects. Employees who take advantage of professional development opportunities show an

\footnotetext{
${ }^{1}$ German social workers hold a university degree of minimum three years after graduating (the German equivalent of) high school. Kindergarten teachers in Germany usually go through a two to four year apprenticeship (differences on the state-level) post middle school. Most often, they do not have any high-school education. According to the collective agreement, kindergarten teachers are grouped in salary level 8, whereas social workers should be grouped in (at least) level 9 or 10. This results in a difference in monthly net salary between 70 and 215 Euro if employed full-time (Öffentlicher Dienst, 2012).
} 
increased level of morale and have lower levels of absenteeism (Rondeau \& Wagar, 2001). Professional development programs have been scarce in FWAs, with some recent exceptions (Marcus, 2008), potentially resulting in a non-existent middle management level with little or no training for leadership roles (Neumann, 2004; Weber, Herzer, Glaser, \& Hanke, 1995). The development of employees in leadership positions is especially problematic. For instance, Neumann (2004) describes the tendency of FWAs to promote front-line employees from within the organization to executive positions. Some of them clearly can meet the challenge of executive management positions, but in many cases, competent professionals often become incompetent managers, which reflects the 'Peter Principle' in FWAs where "every employee tends to rise to his level of incompetence” (Maelicke, 1989, p. 67). These promotion strategies continue and are not conducive to organizational effectiveness, as not all employees are adequately trained to assume leadership positions. Even though executives in FWAs are aware of this situation, few steps have been taken to change this and thus professional personnel development has not played an important role in FWAs (Betzelt, 2001).

Given the heterogeneity of FWAs, it is difficult to make universal assumptions about prevalent HR practices. However, on the basis of the literature reviewed above, it seems that HR practices in FWAs appear ad hoc and bureaucratic with little strategic direction. FWAs, to a large extent, tend to retain the culture under a regime of guaranteed government subsidies and have only instituted change whenever necessary. Ridder, Piening, and McCandless Baluch (2012) in their case study research on FWAs in Lower Saxony, indeed find that their 10 cases differed in HR and strategic orientation, falling into four distinct HR architecture types. The next section briefly reviews strategic human resource management (SHRM) and, based on this, Ridder and his colleagues' framework for nonprofit HR architectures is introduced, which is then used to frame our research findings.

\section{Literature Review}

Strategic Human Resource Management: Human resources contribute substantially to the success of business strategies and overall organizational performance. Human resources, it is argued, are most effectively managed through SHRM, which is defined as "the pattern of planned human resource deployments and activities intended to enable an organization to achieve its goals" (Wright \& McMahan, 1992, 
p. 298). Strategic human resource management, thus, incorporates the resource-based view of the firm, which emphasizes the importance of internal resources to achieve competitive advantages (Barney, 1991; Wright, Dunford, \& Snell, 2001). Those advantages, as argued by Boxall (1998), can be divided into a human capital and a human process advantage. The human capital advantage results from the quality of the employees, the HR base. The organizational processes advantage originates from successful processes that distinguish the organization from competitors (Boxall, 1998). Organizations are only able to achieve competitive advantages, when both human capital and human process aspects are present and mutually aligned.

It is the purpose of HR practices to recruit, develop, and retain a talented workforce that is willing to contribute to the organizational goals (Snell \& Dean, 1992; Wright et al., 2001). The four most prominent HR practices are recruitment, appraisal, development and compensation, whereby all functions "have an impact on performance at both the individual and the organizational level" (Devanna, Fombrun, \& Tichy, 1984, p. 41). However, in order to have the most effective outcomes and to create mutually reinforcing possibilities (e.g. increased motivation), the different HR practices have to be strategically aligned to so called "bundles" rather than being single practices (Macduffie, 1995). Despite this known effectiveness, however, HR practices tend to be implemented as single tools and, to a lesser extent, as systematically aligned bundles in many for-profit as well as nonprofit organizations (Pfeffer, 2007).

A plethora of research has investigated the relationship between HR systems and performance. A common reasoning is the impact of HR practices on employee attitudes and behavior, which positively influences job satisfaction and subsequently increases organizational outcomes. However, the causal relationship might be even more complex, which is one reason for calling the HR-performance relationship a “black box" (e.g. Becker \& Huselid, 2006). For instance, Nishii et al. (2008) argue that employees' perceptions of HR practices even precede their attitudes, suggesting that the employees' individual interpretation should also be considered when evaluating HR practices. Organizations that merely focus on the development and implementation of HR practices while ignoring the perceptions of their employees might therefore be harming the organization. Given the necessity of designing HR practices according to 
external and internal requirements, the authors distinguish internal and external attributions that employees have towards those practices. External attributions encompass situations that lead organizations to design particular HR practices based on legal requirements in the external environment (e.g. union compliance). In their study, employee perceptions of the HR practices reflecting external requirements were not related to employee commitment and job satisfaction. However, employees might also have internal attributions toward HR practices, which in fact can have positive or negative relationships to employee commitment and job satisfaction. If, for instance, employees perceive HR practices to be quality-enhancing, with a focus on employee well-being, their commitment and job satisfaction are likely to increase. On the other hand, if HR practices are perceived to have a cost reduction focus with an underlying focus on employee exploitation, job satisfaction and commitment are negatively influenced. Moreover, independent of the actual HR strategy of the organization, employees might view HR practices differently whereby some could perceive an HR practice as quality-improving and others could regard the same practice as a cost-reduction strategy (Nishii et al., 2008).

In the next section, we will discuss HR practices as well as the link to performance in the context of nonprofit organizations.

Strategic Human Resource Management in Nonprofits: Recent literature has shown that there exists a link between SHRM and performance in nonprofits (Akingbola, 2006; Lengnick-Hall, Lengnick-Hall, Andrade, \& Drake, 2009; Rodwell \& Teo, 2008). For instance, Rodwell and Teo (2004) demonstrate a positive and significant relationship between SHRM and organizational performance among for-profit and nonprofit health service organizations. Research also focuses on external factors such as the environment or organizational characteristics that influence the implementation of SHRM in nonprofits (Akingbola, 2004; Hall, Andrukow, \& Associates, 2008). Guo and colleagues (2011), for instance, find that larger, technologically savvy nonprofits as well as nonprofits that are part of umbrella associations are more likely to implement SHRM approaches.

Given the nature of nonprofits, it is even more complicated to unpack the "black box", which links performance to HR practices. The major reason is the non-distribution constraint, which forces nonprofits 
to funnel surplus back in to their day-to-day business without returning the surplus to shareholders

(Akingbola, 2013). Thus, in contrast to for-profit competitors, who foremost see their human resources as a source of competitive advantage (Barney, 1991), the human resources function in nonprofits is to some extent detached from marked-based principles that are prevalent in for-profit organizations (Eaton, 2000). Nonprofits, contrary to organizations in the private sector, do not aim to maximize shareholder value, rather they try to pursue multiple bottom lines that are linked to the achievement of the organizational mission and social goals (Frumkin \& Andre-Clark, 2000). However, the needs of the internal and external stakeholders might conflict at times, leaving nonprofits with tough decisions to make. For instance, increasing employee satisfaction may or may not increase client satisfaction, and neither may be related to the FWA's competitive advantage in garnering grants from the government.

On a more positive note, Akingbola (2013) identifies distinct advantages for nonprofits in successfully pursuing SHRM. Despite its disadvantage in relating SHRM to outcomes, the non-distribution constraint plays an important role in generating trust among the public and consumers (Handy et al., 2010; Hansmann, 1987). Furthermore, it gives nonprofits access to donations of money and volunteer labor, which generates a relative cost advantage as compared to for-profits (e.g. Anheier, 2005). Moreover, by emphasizing the value-driven (versus profit-driven) nature of their operations, nonprofits have an advantage in recruiting employees in caring professions (Frank, 2004), who are willing to accept lower pay for the opportunity to contribute to society though their work (Benz, 2005; Handy \& Katz, 1998).

Even though the black box is not yet fully unpacked, a basic assumption to understand the effects of HR practices is the necessity of viewing the existing SHRM system as a whole. Those systems are often referred to as HR architecture (Becker \& Huselid, 2006; Lepak \& Snell, 1999). Ridder and colleagues (2010, 2012) recently developed a typology of HR architectures in nonprofits. Their typology is based on the assumption that the type of SHRM that is implemented in nonprofits varies along two dimensions, a strategic orientation and an HR orientation. The strategic orientation emphasizes 1) a vertical fit between the HR practices and the organizational strategy that considers external threats and opportunities as well as internal strengths and capabilities; and 2) a horizontal fit, which postulates that HR practices should be aligned in 
order to have a mutually enhancing impact. The second dimension in the HR orientation is based on employees' needs and motivations and regards them as valuable assets in organizations, hence this orientation focuses on employee retention and invests in their skill development (Nishii et al., 2008).

Depending on the extent to which nonprofits utilize both orientations (low to high), they fall into one of four ideal categories. Those categories are named administrative, motivational, strategic, and valuedriven and are not mutually exclusive (see figure 1). We briefly discuss these categories as we use them to guide our research inquiry.

-INSERT FIGURE 1 ABOUT HERE-

Administrative: This category, low on HR and strategic orientation, is characterized through a lack of professionalism and the absence of a long-term perspective; nonprofits that fall into this category are less willing or able to invest in the potential of their employees, and often tend to imitate HR practices from the for-profit context without adapting them to their specific context (Ridder \& McCandless, 2010; Ridder, Piening, et al., 2012). External funders often influence HR practices (e.g. short-term contracts), which can lead to dissatisfaction among the employees (Akingbola, 2004), and employees are merely regarded as costs that have to be minimized (Nishii et al., 2008; Ridder, McCandless Baluch, \& Piening, 2012).

Strategic: Nonprofits in this category develop HR strategies mostly "responding to market related demands such as funding pressures and constraints" (Ridder \& McCandless, 2010, p. 135). Their HR practices are oriented toward achieving the organizational goals using strategic management methods from the for-profit sector such as staff reduction, increasing workload, and greater emphasis on effectiveness (Ridder, McCandless Baluch, et al., 2012). Their professional development of employees is strategic and focuses on the most promising employees; thus, employees are considered as assets in meeting organizational goals (Ridder, Piening, et al., 2012). However, the low focus on the HR base indicates that nonprofits also tend to disregard employees' needs, which might lead to negative effects on employees' motivation and commitment (Ridder \& McCandless, 2010).

Motivational: This category, high on HR and low on strategic orientation, includes HR practices that strengthen the employees' fit with the organization's mission (Ridder \& McCandless, 2010), which in 
turn is seen as a unique strength (Benz, 2005; Light, 2002). Thus, the motivational architecture emphasizes a commitment-focused strategy that regards employees as valuable assets and consequently invests in their retention (Nishii et al., 2008) by offering benefits such as flexible work hours or family-friendly work policies (Ridder, McCandless Baluch, et al., 2012).

Value-Driven: Nonprofits in this category, high on HR and strategic orientation, focus on strategies that combine the unique strength of their workforce and the organization's values and mission (Ridder, McCandless Baluch, et al., 2012). Investments in HR targeted towards recruitment, development and retention of employees is undertaken to accomplish the strategic objectives of the nonprofit. However, given a values-driven approach in nonprofits, such investment is a goal in its own. Furthermore, value-driven nonprofits struggle to meet the often diverse and conflicting demands of their internal and external stakeholders (e.g. consumers, donors, volunteers \& boards) (Ridder \& McCandless, 2010).

In this paper we draw on this framework by Ridder and his colleagues, to categorize our findings. We further use the perceptions of managers and employees for many of the items within this framework as suggested by Nishii et al (2008) and incorporate them into the HR architecture to understand potential barriers of FWAs to adopt strategic HR practices.

\section{Methods}

Given the importance of qualitative methodology in recent HR research (Ridder and Hoon, 2009), this study uses a pragmatic qualitative approach utilizing ethnographic techniques (Creswell, 2007; Patton, 1990) to study the research questions. In this study, we draw on semi-structured interviews with HR managers and employees working for Caritas, a German FWA. HR systems in nonprofits are strongly built around employee participation (Rondeau \& Wagar, 2001) and we specifically aim to integrate employees and HR managers' perceptions into our research. To understand HR practices (or lack thereof) in Caritas organization, we obtain qualitative data on these practices as perceived by managers and employees. This data is also useful to in identifying the potential barriers faced by FWAs in adopting strategic HR practices. 
Caritas, founded in 1897, is affiliated with the Catholic Church and is the largest umbrella organization of FWAs in Germany ${ }^{2}$. As of 2010, the Caritas employed 559,526 individuals, including 58\% part-time workers, as well as a little more than 500,000 volunteers (Caritas, 2012). The paid workforce is predominantly female $(81.5 \%)$. Caritas operates 24,246 organizations in five major domains (youth welfare services, health care, family support, work with the elderly as well as the disabled and mentally ill) (Caritas, 2010). In 2011, revenues stemmed mostly from grants (49\%), donations and legacies (28.1\%), and the rest from profits, events or membership fees. The share of grant money (mostly given on a project-related basis) comes from the German government (69.61\%), the Catholic Church (13.64\%) and the European Union (3.14\%).(Caritas, 2012). Even though Caritas operates across Germany, Caritas organizations are especially prevalent in more rural and predominantly Catholic regions (Marcus, 2008).

\section{Data Collection}

Our data is part of a larger data from all six umbrella associations of free welfare work. This paper focuses on one umbrella organization, Caritas, and draws on semi-structured interviews with professional HR managers (5) and professional employees (10). The sample was purposive in nature, using snowball-sampling techniques (Bryman, 2008). Purposeful sampling was involved in the selection of 'information rich cases' to recruit informants who are knowledgeable about a subject from personal experience, such as key employees and managers. In this case, we solicited professional social workers and human resource managers employed by Caritas in the federal state of Lower Saxony to provide names of colleagues working in HRM and also names of professional entry-level employees working for Caritas. Those interviewees of the first round were then asked to facilitate contact with former fellow students and/or colleagues, and supervisors. This process was continued until saturation of information was reached (Bowen, 2008; Morse, 1995).

The first author conducted all of the interviews in German primarily by telephone (11), with a few done face-to-face (4). Anonymity was guaranteed to all interviewees with a promise of confidentiality of the data. Length of interviews averaged 27 minutes for the employees, and 38 minutes for the HR managers.

${ }^{2}$ Free welfare associations are organized in six centralized umbrella associations of free welfare work (Spitzenverbände der freien Woblfahrtspflege). These six entities serve as umbrella organizations for their members, and are either religiously affiliated (Caritas, Diakonie, Jewish Welfare), politically affiliated (Worker Welfare - social democratic), non-partisan (The Parity), or affiliated with the Red Cross (BAGFW e.V., 2008). 
Guiding the semi-structured interviews were the following questions: If you were able to change anything you like in your organization, what would you change and why? HR managers were probed using a similar interview instrument with different semi-structured questions related to their experiences in FWAs and current challenges in human resource management. Interviews were digitally recorded and then transcribed.

\section{Data Analysis}

In the first step of the analysis, analytic induction and constant comparison strategies were used to elicit common themes regarding current HR practices and perceptions. These themes emerged from the data during initial coding and were identified by going back and forth between the interview transcripts and the emerging theoretical understanding (Glaser \& Strauss, 1967). After coding these themes, the interviews were searched for instances of the same or similar phenomena. This process was repeated until all findings were coded. In a next step, we then investigated to what extent the themes we found aligned with the framework developed by Ridder and colleagues. Members of the research team worked sequentially and then collaboratively on this stage of research to maintain the credibility criteria of the study. Disagreements in assigning themes to categories were carefully discussed among the researchers to reach consensus. The findings discussed below are supported by direct quotations from the interviewed HR managers and employees; however, these quotations are not exhaustive of their contributions in each category.

\section{Sample Characteristics}

All 15 interviewees held professional degrees, and the 10 employees are in entry-level positions in FWAs. Their professional backgrounds were predominantly in social work (2 managers/5 employees) and health care (2 employees). The remaining employees held degrees in political and social sciences as well as theology. The remaining HR managers were trained in business management, public administration and education. Fifty percent of the employees had a short-term contract; two were employed part-time. HR managers were employed full-time with open-ended contracts.

The employees worked in 10 different Caritas organizations. Six of the entry-level interviewees worked in youth-related services and were front line service employees, whereas four worked in regional 
offices that coordinated local Caritas organizations. They worked in management such as human resources and finance, or administrative positions such as fundraising, marketing, and public relations. Three of the HR managers worked as well in regional associations where they were responsible for HR for employees (30-120) within the regional office in addition to the HR for managers (30-40) of smaller member organizations in Caritas. The remaining two HR managers were executives of child and youth welfare organizations with 30 and 160 employees, with HR being one of their responsibilities.

The female share of the interviewed employees was 50 percent and 30 percent for the HR managers. The employees had an average age of 29 years; with an average length of employment was 2 years for the employees and 16 years for the HR managers. This sample reflects the nature of the workforce of FWAs, which is largely composed of social or welfare workers with employment ranging from part-time and full-time paid workers (BAGFW e.V., 2008; Vilain, 2002).

\section{Findings}

We present our findings using the four categories developed by Ridder and his colleagues (2010, 2012). Another category that emerged in our findings was 'external context' influencing the structure and implementation of HR practices in Caritas organizations. Given the rather deterministic nature of this category and the influence of the external context on the actual HR practices, we start with this category, and describe the themes that emerged. Thereafter, we discuss the themes in the four categories: administrative, strategic, motivational and value-based HR architecture.

\section{External Context}

For this category, two themes emerged from the data. The first theme relates to the External Environment, while the second relates to changes in Changes in Demographics and Labor Supply.

\section{Policy Environment (Funding \& Competition)}

The HR managers reflected on their struggles with keeping up their services in the face of decreasing funds and the changing nature of government contracts. They reported difficulties in acquiring long-term governmental funding, which led to challenges in planning. A male HR manager indicates, "Funds for 
refinancing are falling away, [...] labor costs, energy costs are insufficiently funded. On the other side more and more quality is demanded from the nurses and from medical services" (H1, 84-87). Another male HR manager adds,

"Previously we used to have long-term contracts with municipalities and with counties, because they said, 'we want to provide certain social services in our district and will offer financial resources for it'. This funding has now decreased given the current situation of the municipalities and counties, we have funding contracts for only one year" ( $\mathrm{H} 2$, 96-102).

Cutbacks in public funding had direct consequences on strategic planning for Caritas organizations.

Accompanying these cutbacks, the government started to give out contracts and grants on a competitive basis and thus organizations such as for-profit organizations previously unable to receive government funding were competing alongside FWAs. The barriers to entry were lowered, and competition undermined the monopolistic position hitherto held by FWAs. Caritas now faced a competitive market situation with which they lacked experience (Marcus, 2006). The impact of competition was especially severe for recruiting and retaining qualified employees as well as pricing services, as these HR managers point out:

"Caritas is now not the only [provider] who offers such services, but there are a lot of other social service providers in the market [...], especially in urban areas. Consequently there is the competition for good employees" (H2, 64-72).

We currently face competition of 35 or 36 private providers of nursing services. [...] When we offer a price for basic nursing, the private provider offers a lower price. At this point, we are out of the market, even though our price is very tightly calculated" (H1, 272-316).

As a reaction to decreases in public funding, a new collective agreement (TVÖD) was put in place by a majority of FWAs that allowed for more flexibility in remunerating structures. This new agreement does not change salary levels for inexperienced employees, but it affects the recruitment of experienced or trained professionals, as wages are now dependent on length of service within FWAs. Thus, HR managers cannot offer wages that reflect experience or training when recruiting experienced skilled employees, as noted by this female HR manager of child welfare services:

"A very big challenge is the current financial cutbacks and the change of the wage system. It is true, that nothing changes for young employees, but if you search for staff with experience and who did not previously work for a FWA, then taking employment with FWAs results in enormous financial losses for the employee. Clearly this is difficult, there are areas where I need experienced workers, because someone without experience, professional experience, is not able to handle [the job]" (H3, 57-63). 
HR managers are well aware of the challenges caused by the policy environment, which are beyond

their control. Those external factors clearly influence how organizations go about their HR practices.

\section{Changes in Labor Supply}

Besides challenges that were initiated by the government as an outside actor, societal trends further impede Caritas organizations in their ability to recruit qualified employees. One of those trends encompasses demographic changes of an aging population, which leads to an increasing demand for services and shortages of qualified personnel (Buestrich et al., 2008).

"Other challenges are caused by demographic changes; this is clearly noticeable. Especially in nursing services or in terms of social workers, I would say that in 2015 it will be a tight squeeze to get enough personnel. Even currently there are difficulties, [...] but it will get even harder to find qualified people given our working conditions" (H1, 116-122).

The reputation of FWAs has fallen in society and this creates difficulties in recruiting professionals to social service jobs in Caritas (Neumann, 2004; Oliva et al., 1991). Several employees specifically refer to the low overall value that society gives to social service work. For instance, a male social worker states, "The problem is simple; society does not necessarily value social work or other such services $[\ldots]$ the area in which we work. [...] What we do has not a high significance" (G15, 172-175). Another female social worker explained that she had to "defend the profession in and of itself because of the low societal presence" (G13, 102-104).

Organizations, however, continue to rely on recruiting employees willing to work in social services and who share their ideology to increase the fit between the individual and organization as indicated here:

"welfare associations, churches or political parties are to some extend organizations pursuing ideological aims [Tendenzbetriebe], where you need a certain affinity to properly work there and this is the biggest challenge" (H5, 81-86).

Furthermore, due to the general loss of relevance of the church in society, it is even more challenging for Caritas to find people who identify with Christian values (Marcus, 2008). HR managers underscore these findings; "religion and the church are increasingly irrelevant or play a lesser role in the private sphere" (H1, 326-340). More specifically to the younger population, they find that: 
"[...] things are starting to change, $[\ldots]$ church as educational institution does not fit to the life expectations of many people any more. [HR managers] realize that the part of young people who naturally grow up in and with the church declines" (H5, 105-115).

This poses immense difficulties for Caritas, because religious FWAs require identification with

Christian values upon employment (Beyer \& Nutzinger, 1993).

Overall, the description of the external context as perceived by HR managers and employees illustrates the environment in which Caritas organizations operate. Changes in funding and an increase in competition for funds accompanied by societal changes challenge HR managers and potentially influence HR practices in Caritas.

\section{Administrative HR}

For this category, three themes emerged from the data. Those are short-term contracts, cost-cutting strategies and compensation levels within Caritas organizations

For the first theme, compensation levels, we identify a disconnect between the HR managers and employees" perceptions in certain key areas. Some HR managers agree that "the Catholic church is a top payer" (H2, 146) and that the collective agreement provides "fair compensation" (H3, 214).

Employees, for the most part, were dissatisfied with their earnings, as one employee indicates: "As social worker, one does not lie on a bed of roses" (G7, 170). Another employee follows this line of reasoning and expects the pay to be appropriate in order to increase motivation and satisfaction levels as illustrated here: "I expect higher pay for the work that I am doing. I enjoy my work less and less because of the low pay. $[\ldots]$ What we are paid is ridiculous" (G15, 136-138).

Compensation levels might be evaluated differently, depending on the organizational context. In case of other potentially positive factors, such as work conditions, low pay might be outbalanced (see next category). Given the restrictions imposed by the collective agreement, Caritas organizations do not have much leverage to change current payment levels.

Even though, some FWAs tend to implement performance-based payment systems (EKD, 2002; VdDD, 2013), this was not the case in our sample. One employee, however, specifically addressed the advantages of these systems: 
"If I were paid according to performance and not according the collective agreement, I would work harder. I often think about this; if I had to reach a certain goal by the end of the year and they offered me a certain amount when I reach my goals... I think that would give me a high motivation. But that's difficult to measure, especially in social work" (G15, 175-180).

The second theme in the administrative HR category is short-term contracts. As a result of

decreased efforts to be more competitive, Caritas organizations are unable to offer their employees long-term contracts, which include costly benefits of tenure (Dahme \& Wohlfahrt, 2007; Wohlfahrt, 2012). Short--term, project-related contracts force uncertainty on HR managers:

"This means that employees have to be hired short-term. One knows that a certain project runs for a year, by then it has to be completed, even though it may be extended for another year. [...] That is not satisfying for us and not for the employees. It influences recruitment, since we only can advertise short-term contracts and you do not get the applicants' quality that we wish for" (H2, $102-110)$.

With short-term contracts, HR managers are unable to attract the kind of employees they need to sustain their services, which leaves them with a shortsighted HR recruitment strategy. HR managers perceive the environment as increasingly insecure and uncertain; services once provided, however successful, are not certain to continue as they are entirely based on achieving success in the next round of the grant competitions. As research indicates, in the absence of long-term commitments from the employer, employees take on shortterm perspectives in their engagement with their employer, resulting in decreased attachment and loyalty and ultimately in turnover (Pfeffer, 2007). Entry level employees in FWAs, even though they highly value flexibility, expect a certain level of job security that contributes to their satisfaction (Walk et al., 2013). If they do not find this security, they are likely to leave. One interviewee working for a youth associations explains the situation:

"In the past 15 months, we have seen three changes for the two positions we have. [...] Even though, the jobs offers a variety of possibilities, the structure and the work conditions are less than optimal to stay here long-term" (G10, 277-289).

The third theme that arises is the cost-cutting strategies implemented in reaction to the cutbacks in funding. One of the HR managers points out that his employer, a regional association that offered various kinds of social and health care services, heavily downsized the nature of nursing services, such as hours spent with patients, and other related costs. He continues, 
"I think, this approach [cutting down on nursing services] was correct, but it is exhausted by now. Principally, the margins on savings are maxed out. Controlling has squeezed out everything. The next step are only mergers, for instance three nursing homes get together and decide to have one management only; to work together, to have only one kitchen and not three. Partly we have seen such changes and we will see more, but at some point this will be exhausted too. And all of this does not leave our staff members unaffected. The story is simple: we have to fulfill more tasks, including quality management, with less staff' (H1, 246-251).

HR managers acknowledge the limits of their cost saving approaches in dealing with the financial

cutbacks. However, they are now concerned with maintaining the quality of their services and the effects on the employees.

\section{Strategic HR}

For this category, the following two themes emerged from the data: lack of strategic HR practices and professional development (needs and existing opportunities).

The individual organizations under the Caritas umbrella differ in their HR practices since these organizations are independent in their day-to-day organizational processes, as this manager in the regional office points out:

"[There are] some associations and areas, where certification processes in terms of quality management are completed, some achieved good results, those are in good shape, but others, they have not even started with the topic. [...] To bring everyone on the same level, I need to have one strategy to accurately measure their goals and levels of service" (H1 181-194).

HR managers clearly see the need "to put the whole thing under one roof, to make it more strategic"

(H1, 180-181). Although the need for a more strategic and a less ad hoc HR approach is clear to the managers, they cite the lack of time to develop strategies as an obstacle. Furthermore, HR managers regard their working climate as being filled with uncertainties that does not allow them enough time for strategic thinking and long-term planning, as indicated here:

"In terms of my current field of work, I wish to have more time for conceptual work, to focus on the basics and to think through the strategies we need, but due to the dayto-day work, things are just managed as they occur. This means that we only could do strategic planning if we could afford more staff to do the everyday work. I truly believe that this would be an investment for the future" (H1, 489-495).

The need for a strategic approach toward HR practices is also obvious to the employees. One female social worker points to the need to strengthen HR practices, "[...] although there is a lot is already going on, 
it is not strategic enough; especially in regard to appraisal interviews or more general in terms of addressing the needs of older colleagues" (G13, 194-197). In general, employees feel that organizations do not react unless they "face an urgent need for action" (G10, 241). This perception is consistently found in the interviews.

The managers agree that "an absolute utopia" (H3, 335) requires resources that are simply not available. They do not want to react in an ad hoc fashion to external policy changes, and advocate a reflexive approach as suggested by this question from an HR manager: "What do I want strategically as an employer?" $(\mathrm{H} 3,317)$. Whereas the managers' concerns encompassed the overall strategic orientation of the organization, they were ambivalent in terms of the right approach. On the one hand, managers were struggling with the tradeoff between the Strategic and the HR orientations, as exemplified here:

"At times, you have to 'slightly force' the people to do their tasks. Similar to job satisfaction, you have to balance what is good for the individual and what do I need for my organization. [...] You have to make a decision — do the wishes of the employees determine the organizational goals or vice versa?" (H5 241-205).

On the other hand, other managers specifically pointed to lack of strategic HR practices in recruitment strategies

"We need to think about [...] procedures that enable us to recruit and develop more strategically. [...] To date, we had lived off the good times, where we had sufficient applicants, and we did not need to recruit. Now we face shortages and need to arrange incentives and structures appropriately to attract employees and show we are good with something unique to offer" (H3, 329-344).

Professional development, as the second theme of this category, appeared in interviews with both employees and managers. The first sub-theme is the need for professional development; the second subtheme is related to the existing professional development opportunities.

According to one manager, Caritas could deal better with the external environmental changes if employees fulfilled certain criteria, they

"should regard changes as positive and should be willing to participate in those changes. Willingness to change is a basic qualification that everyone should have. Providing appropriate professional development can teach employees how best to change, and be willing partners" (H2, 207-210). 
HR managers emphasize the need for regular professional development, "to encourage and support everyone, broaden their horizons and prevent them from standing still" (H1, 346-361); and they advocate for a proactive approach towards development.

In conjunction with this, HR managers also emphasize the need for long term career planning as indicated by the following questions:

"Career planning should be part of our strategic initiative: 'where do we [organization], want to go?', 'where does the employee want to go?', 'what kind of ideas does he have?' and 'what we can imagine, what's realistic and how can we help with the process? " (H1, $353-359)$.

As much as employees need professional development in order to adapt to ongoing changes, HR managers point out that it would be beneficial if all employees (including themselves) were regularly included in development strategies. This is indicative in the following quote by one manager:

"It is one thing to offer development possibilities for non-managerial employees, but we in the management team also have a huge need for professional development. We all grew into our positions [...] We are all educators [Pädagogen] by training it is expected that we have know-how of certain business management and legal regulations, but we are all-rounders, who know a little bit of many things but do not have particular expertise, especially in management" (H3, 277-282).

Executives in the sample arrived at their positions by rising through the ranks in the organization and as such, often lack the skills or experience in management, following the traditional Peter Principle (Maelicke, 1989; Marcus, 2008).

The second sub-theme was the perceptions of existing development possibilities in Caritas organizations. Employee perceptions were diverse and although some employees were dissatisfied with the development options others were satisfied or indifferent. One dissatisfied employee says:

"Professional development? That does not exist. Once a year we have training for all employees. It's called training, but it is actually only a day where you listen to a presentation. That is then called training. The only way to further education yourself is through taking educational leave or vacation days" (G7 232-236).

Other employees feel that they have good possibilities, but the initiative is on the employee, as

indicated by this employee:

"Professional development possibilities are given to us. If development requests exist and if opportunities are available, [the employer] supports improving oneself.... We do have a professional development, but it is differentiated. For social work it is essential to continuously educate yourself, without which you will not be recognized or progress. 
But it is different for administrative employees. Here at the initiative of the employee...you request professional development, if you see a need" (G8, 100-112).

Employee perceptions regarding the selectivity of professional development correspond to the perceptions of HR managers. One manager explains that, they "choose, who attends further education, because [they] try to disperse knowledge in a way that [they] can use this knowledge strategically for the organization" (H3, 120-121). Closely related, another manager refers to their intention to further develop employees and the difficulties in doing so:

"We want to give employees a possibility to move up, we want them to have a career. But every organization only needs one executive director, that's clear. Leadership positions are limited, but that's the case everywhere" (H4, 101-104).

The data show a strategic HR architecture, where professional development is selective (Ridder,

McCandless Baluch, et al., 2012).

\section{Motivational HR}

For this category, we identified three themes in our data analysis that were specifically used to emphasize a high HR orientation: work conditions, on the job training, and appraisals.

Due to the non-distribution constraint and the collective agreement, HR managers in our sample realize they "cannot offer monetary incentives such as bonus payments in the business sector; [we] simply do not have this freedom" (H3, 360-363). HR managers concede that their employees are not solely driven by monetary rewards. Instead, they emphasize that providing good work conditions is critical for recruiting and retaining qualified personnel, as one manager points out:

"Money is not everything. It is good to have money, but you need something else, you need a work atmosphere with greater participation where you have a voice. [...] If I have an immediate supervisor who does not listen to my ideas, or treats me condescendingly, the social aspect of the work climate decreases and a pay raise cannot make up for this" (H5, 152-157).

Managers recognize that the work-climate needs to be positive for employees to stay motivated:

"Work conditions have to be suitable. Employees have to be at a workplace where they say 'I can really work here', and where the working climate is comfortable" (H4, 86-93). HR managers referred to certain initiatives such as increasing decision-making possibilities and autonomy within teams in order to create a comfortable work environment and offering a work-life balance to their employees. For the sake of brevity, we are 
referring to the availability of flexible working hours here, to illustrate how Caritas organizations aim to increase work motivation and employees. Flexible working hours were widely available to employees, but HR managers also expect their employees to reciprocate these freedoms to some extent as mentioned here:

"Flexible working hours work well here, employees do not have to clock in or out, and nobody controls them. But on the other hand, we do have the expectations that our employees are flexible. We expect, if necessary and a child has an emergency, that the employees stay longer" (H3, 220-225).

The mentioned initiatives have a strategic component as well as explained here:

"Employer attractiveness is important and Caritas is very attractive, especially for young women, and for women after maternity leave, and we want to communicate this externally and want to be known as a great employer to work for in Germany" (H2, 149-152).

However, these initiatives are extremely difficult to implement in practice, since HR managers

observe that the overall work environment in Caritas organizations changed as a result of changes in public funding. Employees face an increased workload, especially in terms of administrative tasks such as filing documents for quality management (Dahme \& Wohlfahrt, 2007).

Regardless of the efforts on behalf of the HR managers, the overall work environment is difficult especially for older employees, as indicated by the following quote:

"The problem the work requires to work at inconvenient working hours for instance in nursing homes. [...] We see incidences of burnout among the older the employees who find it [night shifts] difficult which becomes even more acute due to their physical limitations" (H1, 91-92, 221-223).

Caritas organizations are often not equipped to be able to tailor jobs to the changing needs of an

aging workforce. Another female HR manager in youth welfare services adds:

"We have some employees who are 55 years and older in a home for children, where the work is physically demanding. However, what can I do? [...] We are not a large company with many departments where I could move these employees to other departments and accommodate their needs. That's simply not possible" (H3, 261-266).

The motivational HR architecture intends to strengthen both mission attachment and the fit between employees and the characteristics of their organization (Ridder \& McCandless, 2010), which HR managers

perceive as difficult as illustrated here:

"Maintaining the balance between the organizational values and external economic challenges is becoming more and more difficult. Managers have to endure this situation and inform and integrate the workforce in order to achieve a balance. Every day is a challenge and it is becoming increasingly difficult" (H1, 160-164). 
In order to achieve this balance, and following the motivational HR principle, one of the regional headquarters counteracts the pressure that external challenges pose on employees by "offering spiritual counseling and meetings that [the employer] organizes within working time and at the expense of the employer" (H1, 165-166).

On-the-job training, the next theme, was an important concern for managers, where on-the-job training was regarded as an important HR practice whereby new employees

"Have someone who accompanies [them] when they join. We need a concrete checklist that mentors can use to make sure that content of the job is discussed, not leaving anything to chance. [...] That would guarantee a faster integration into the organization and into the team" (H1 398 - 405).

In practice, the way on-the-job training programs are implemented depends on the organization and the executives on-site, as one manager of a regional association explains:

"Some organizations have not done anything [regarding on the job training] and there is a need for change. [...] We, as regional office have to provide a good example [...] we offer on the job training concepts for new executives. In part those are very successful and we aim to implement those positive experiences in other areas where they are still lacking" (H1 386-420).

Although job training is regarded as desirable by HR managers, implementing training on-the-job is difficult, as "there are a thousand things that are drowned up in day-to-day routine, furthermore, the employee who manages the job training must do it in addition all the rest of his work, which makes it difficult to train new employees" (H1, 402-405). Lack of time is indeed one of the main reasons for the absence of comprehensive on-the-job training programs.

The next theme that emerged was appraisal as HR practice, which is a significant component of motivational HR. Although our interviewees, managers and employees, emphasized the importance of appraisal interviews, HR managers acknowledged that there is no overall system of appraisals in terms of their regularity and structure across Caritas organizations. In one organization, "All employees have appraisal talks, at least, every employee has the right to an appraisal talk $[\ldots]$ and to a large extent they are conducted, at least once a year" (H2, 83-92). But even though employees have the right to appraisal talks, organizations handle appraisal interviews "in a relatively decentralized way" (H4, 89-90). Some organizations offer relatively 
structured talks following an official guideline, while other organizations appraisal talks were undertaken on an ad hoc basis "when employees have problems that they want to discuss" (H1, 111-112).

Employees highly valued appraisal talks. However, similar to the HR managers' perception, they perceived the extent and quality of these talks to vary, and some organizations did not provide appraisal opportunities at all. One employee explains this situation:

"If we look into the area of appraisal interviews for example or just a regular exchange [between employees and their supervisors], I have to say that it's just not happening. On the one hand, one could argue that the responsible people do not have the skills needed to conduct those talks. [...]. Unless something happens that requires action, nothing happens" (G10 204-216).

Overall, we find that HR managers are concerned with the motivation of their employees and want to create work conditions in which employees can grow and feel comfortable. Unfortunately, the extent to which HR practices of the motivational HR architecture were integrated varied substantially between the organizations we interviewed.

\section{Value---based HR}

The main themes that emerged in this category were religious values and organizational identification.

A value-based HR implies that Caritas attracts those employees whose values match those of the organization. The managers also emphasize a value based fit in recruiting: "In addition to the professional qualification of the individual for the job, personal values and fundamental convictions [are important]. [...]

New employees need the professional qualification and a spiritual foundation and have to fit into the existing teams" (H5, 92-95, 299-300). Among the ten interviewed employees, four (G13, G10, G15, G17) also mention this value-fit; they consciously made the decision to work for a faith-based organization. Working for organizations with a different value-base was seen as being rather critical; one of the employees mentioned that he would only work for a Protestant organization, if there was "no other option, but [he] would always give preference to a Catholic organization" (G17, 95).

However, the changing nature of the workforce, as explained earlier, posses difficulties to achieve this fit. Although working for a faith-based organization is still important for some, which is not the case for everyone, as one manager reports: 
"Caritas is a reliable employer for many and they support who we are. But I think it is not important for everyone that we are a faith-based employer, but that does not bother me. [...] But all of them accept our mission and values and come to terms with the structures. For the majority of the current employees, it is indeed a consciously made decision and they live out our values, but certainly not for all. To think that would be presumptuous nowadays". H3, 194-199

Similarly, HR managers find that current applicants do not always identify with Caritas and simply

say, "I don't have problems with the Catholic Church" $(\mathrm{H} 1,330)$. This lack of value fit with Caritas leads

managers to make difficult compromises:

"the probability of finding a Catholic executive who also has the required qualification and necessary experience, is low. I must somehow find a compromise. However, finding this compromise is difficult, given the rigid guidelines under which Caritas operates" (H1, 135-139).

The second theme in this category was organizational identification. Here, HR managers emphasized the strategic value of employees' identification with the organizational values, which often challenges them in their day-to-day business as illustrated here:

"We motivate through identification [with our values] and we try to provide a good environment despite difficult conditions [...]. We constantly debate - and I do not mean solely religious or theological - about our distinctiveness as organization, what defines us as Caritas, as employer. Where do we distinguish ourselves from others?" (H1, 160$165 ; 310-312)$.

Organizational identification also leads to some interesting consequences among the clients of

Caritas. For example, Catholics often identify with Caritas, expect Caritas to deliver services based on

religious values, and act on Christian values. For example, one HR manager discussed a situation in which a

client had died and he struggled with the decision of whether or not to send the nurse who had cared for this

client to the client's funeral. Due to tightly calculated budgets, the nurse could not be paid for this service,

but she was expected to attend it on her own time. He continues:

'If Caritas is not sending its nurse, people talk and say: 'Look, that's Caritas!' As such this problem is specific to Caritas, due to our religious values; our private [for-profit] competitor does not have this problem. We would like to pay our employees for this kind of service, but cannot afford it. Within the context of values, we tell our employees that we expect them to go. This is a contribution that you have to make, but unfortunately we cannot pay you for it. [...] But here it becomes clear how hard it is to manage this balancing act. Where do we emphasize [our values] and at what price? To what extent can we demand or expect this from our employees?" (H1, 283-316).

Caritas is constrained to work with fewer economic resources and finds it difficult to actualize its

Christian values and to expect organizational identification amongst its employees, although clients continue 
to expect it of them. Interconnections between such value-based HR architecture and the external influences make it difficult for Caritas to continue to be simply a value-based organization.

\section{Discussion and Conclusion}

In this paper we investigated the perceptions of HR practices of HR managers and employees in FWAs, drawing on Caritas, which is the leading umbrella organization of Catholic welfare work in Germany. Qualitative semi-structured interviews were used to generate data to understand the internal and external influences on HR practices. By eliciting responses from employees and their managers, we generated data on both perspectives. Furthermore we examined if there were gaps between the realities of what is feasible with what is desirable in effective HR practices.

We used Ridder and his colleagues' model of HR nonprofit architectures as a guiding framework for our analysis. The findings allow us to extend their model as seen in Figure 2, which show that many of the resulting HR practices are largely precipitated by (1) policy changes by the government and (2) the changing supply of labor.

\section{- INSERT FIGURE 2 ABOUT HERE -}

External Factors: Changes in the external environment that influenced the internal environment of Caritas are twofold: First, the new government policies changed who can provide social services, and this introduced competition in the market as well as uncertainty in obtaining funding. Thus, Caritas found itself competing with other FWAs and for-profit providers (first-time entrants into the market that was otherwise restricted to FWAs). As these changes came about relatively rapidly, the highly bureaucratic nature of Caritas hindered a coherent response to the changes and hence the ad hoc responses that were generated were unsatisfactory to both managers and employees. For example, our findings indicated that because government funds are now granted on a competitive and short-term basis, Caritas could only offer employment based on the length of these contracts, which impacted employee morale.

Second, the changes in the labor supply due to changing demographics decreased the supply of available employees who identified with the Catholic Church. When recruiting employees, Caritas is constrained to hire those who share values of the Catholic Church, but faces a decreased supply of skilled 
recruits for both entry level and executive positions. And when skilled recruits are available, they are often indifferent toward the organizational values, especially regarding the Christian values of Caritas. Thus the interaction of external changes on internal processes exacerbates the influence of external factors and hinders the development and implementation of comprehensive HR bundles.

Ridder, Piening, et al. (2012) in their case study analysis of FWAs in Lower Saxony, also acknowledge the uncertain environment in which FWAs operate, but the nature of those uncertainties and their influences on the HR architecture remain unclear. Our paper extends their model to include a more extensive inquiry into the effects of the external environment and confirms previous empirical research on FWAs. Furthermore, we describe the nature of the current external challenges FWAs face (e.g. changes in the external policy environment, societal changes) and show that the external context influence HR practices in FWAs, regardless of the HR architecture that is implemented in the organization. Our paper, thus, adds a new dimension to the current literature on HR practices within FWAs, the major provider of social services and health care in Germany.

Incorporating employee and HR managers' perspectives enabled us to get an in-depth insight into current HR practices in Caritas organizations. Perceptions of HR practices between these groups overlapped in some areas but differed in others. We are mindful of Nishii et al. (2008), who caution that perceptions could be independent of the actual HR strategy of the organization. Even if perceptions do not accurately reflect the HR practices, we believe they are important in eventually influencing employee satisfaction and commitment. Therefore, it is important to incorporate these perceptions, since they help to further unpack the black box between performance and HR practices (Nishii et al., 2008).

Structuring our paper around the framework of HR architecture developed by Ridder and colleagues helped disentangle the different perceptions of HR practices present in our interview transcripts. Our findings indicate that Caritas organizations faced unique struggles in implementing effective HR practices. Some of these challenges could be ameliorated by aligning the major HR practices of recruitment, appraisal, development, and compensation, to HR bundles that reflect the overall organizational strategy and are 
utilized to reach the specific organizational mission (Devanna, Fombrun, \& Tichy, 1984; Macduffie, 1995), and we suggest four strategies..

First, given the difficulties in recruiting employees that have a similar value base, Caritas organizations might collaborate with regional schools and universities, especially those affiliated with the Catholic Church. Through projects and internships in social work, health care, or nonprofit management, Caritas could build relationships with students who identify with the Catholic Church. Furthermore, through such relationships, students would develop an understanding of the challenges faced by Caritas, and adapt their job expectations when seeking employment in the field (Walk et al., 2013). For Caritas, such internships give them access to a cohort of potential employees, increase their visibility, and allow them to recruit suitable candidates who they have had the ability to observe and evaluate.

Second, despite changes in funding that force FWAs to comply with outside short-term oriented regulations, we emphasize the importance for Caritas to implement long-term contracts and take the inherent risk of not being funded. Keeping a pool of qualified and committed employees could pay off when FWAs land new contracts, because FWAs would not have to recruit new untested people, a costly process in an environment with a shortage of suitable candidates. When between projects, the long-contracted employees could receive professional development or be deployed to other projects, or their time could be traded off for the overtime accumulated in high stress periods. This would allow Caritas to retain well-trained, satisfied employees who would otherwise face job insecurity.

Third, given their inflexible wage structure under the collective agreement, FWAs do not have much leeway to increase salary levels or offer discretionary bonuses. As our findings show, although HR managers already focus on improving work conditions for employees (e.g. flexible working hours, decisionmaking autonomy), other initiatives could be deployed, such as professional development and increased options for job trainings that would allow employees to move within the organization in a way that recognized their changing physical limitations (for older employees) or interests.

Finally, given the positive effect on employee motivation, appraisal and professional development possibilities should be strategically aligned (Macduffie, 1995). Appraisal interviews, an effective HR practice, 
are not widely utilized in our sample organizations. Linking appraisal with professional development will be beneficial for Caritas, if supervisors focus on the employees' strengths and weaknesses in order to maintain the former and mitigate the latter. Currently, appraisals are often ad hoc and sometimes only available to employees upon request, and we suggest that a more pro-active approach might be beneficial. Such proactive efforts may include appraisals which take a long-term perspective for an employee's professional development, which could even extend beyond the employee's tenure at the organization. Such career planning could help employees to understand plans the employer has for them in the future and lead to increases in job satisfaction. Thus, appraisals should incorporate career planning as part of the individual development plan in order to best meet the organizational goals as well as to satisfy the needs of the employees.

This research is not without limitations. The snowball sampling technique might have led to a selection of employees with limited viewpoints, with only those employees and HR managers participating who were highly satisfied or dissatisfied with their current situation. The interview findings here are not generalizable beyond Caritas organizations, even though Caritas is similar in structure and size to other umbrella organizations of FWAs (BAGFW e.V., 2008). Following Nishii et al. (2008), future research should survey the perceptions of HR practices of a larger number of employees and managers using a quantitative survey instrument created based on our findings and targeted to FWAs. Using quantitative research methods, it would be possible to compare FWAs of different affiliations, size, areas of welfare work, and other organizational characteristics that may influence the findings.

Nevertheless, this paper provides an attempt to understand the perceptions of HR practices by HR managers and employees at a time when FWAs face a challenging and a fast changing outside environment. This paper provides valuable groundwork on SHRM in a German context. Given that FWAs are the largest nonprofit employer, with over 1.5 million employees, HR practices in FWAs impact a sizable working population in Germany (BAGFW e.V., 2008). 


\section{References}

Akingbola, K. (2004). Staffing, Retention and Government Funding. Nonprofit Management \& Leadership, 14(4), 453-465.

Akingbola, K. (2006). Strategy and HRM in Nonprofit Organizations: Evidence from Canada. International Journal of Human Resource Management, 17(10), 1707-1725.

Akingbola, K. (2013). A model of Strategic Nonprofit Human Resource Management. Voluntas, 24(1), 214240.

Anheier, H. K. (2005). Nonprofit Organizations. Theory, Management, Policy. New York \& London: Routledge.

BAGFW e.V. (2000). Einrichtungen und Dienste der Freien Wohlfahrtspflege Retrieved August, 2011, from http:/ $/$ www.bagfw.de/index.php?id $=513 \&$ no_cache $=1 \& t x \_t t n e w s \% 5 B t t \_n e w s \% 5 D=227 \& c H a s h=$ af55976110

BAGFW e.V. (2006). Gesamtstatistik Retrieved February, 2011, from http://www.bagfw.de/uploads/media/m01054_8f1862a06c949d844bf46f871bf9dee1.pdf

BAGFW e.V. (2008). Einrichtungen und Dienste der Freien Wohlfahrtspflege Gesamtstatistik 2008

Retrieved February, 2011, from http://www.bagfw.de/uploads/media/GS_BAGFW_091221_web_01.pdf.

Barney, J. B. (1991). Firm resources and sustained competitive advantage. Journal of Management 17(1), 99-120.

Becker, B. E., \& Huselid, M. A. (2006). Strategic Human Resources Management: Where Do We Go From Here? Journal of Management, 32, 898-925.

Benz, M. (2005). Not for the Profit, but for the Satisfaction? - Evidence on Worker Well-Being in Non-Profit Firms. Kyklos, 58(2), 155-176.

Betzelt, S. (2001). The Third Sector as a Job Machine? Conditions, Potentials, and Policies for Job Creation in German Nonprofit Organizations (Vol. 2805). Frankfurt: Peter Lang GmbH.

Beyer, H., \& Nutzinger, H. G. (1993). Hierarchy or co-operation: Labor-management relations in church institutions. Voluntas, 4(1), 55-72.

Borzaga, C., \& Depedri, S. (2005). Interpersonal Relations and Job Satisfaction: Some empirical Results in social and community Care Services. In B. Gui \& R. Sugden (Eds.), Economics and Social Interaction: Accounting for interpersonal Relations. Cambridge: Cambridge University Press.

Borzaga, C., \& Tortia, E. (2006). Worker Motivations, Job Satisfaction, and Loyalty in Public and Nonprofit Social Services. Nomprofit and Voluntary Sector Quarterly, 35(2), 225-248.

Bowen, G. A. (2008). Naturalistic inquiry and the saturation concept: a research note. Qualitative Research, 8(1), 137-152.

Boxall, P. (1998). Achieving Competitive Advantage through Human Resource Strategy: Towards a Theory of Industry Dynamics. Human Resource Management Review, 8(3), 265-288.

Brinkmann, V. (2008). Personalentwicklung und Personalmanagement in der Sozialwirtschaft. Wiesbaden: VS Verlag für Sozialwissenschaften.

Bryman, A. (2008). Social research methods. New York: Oxford.

Buestrich, M., Finke-Oltmann, F.-P., \& Wohlfahrt, N. (2008). Aktuelle Entwicklungen des Personaleinsatzes in sozialen Diensten und Einrichtungen: das Beispiel „Pflege“. In V. Brinkmann (Ed.), Personalentwicklung und Personalmanagement in der Sozialwirtschaft (pp. 63-104). Wiesbaden: VS Verlag für Sozialwissenschaften.

Burmester, M. (2005). Die sozialwirtschaftliche Bedeutung der Freien Wohlfahrtspflege. In H.-J. Dahme, G. Kühnlein \& N. Wohlfahrt (Eds.), Zwischen Wettbewerb und Subsidiatirät. Woblfahrtsverbände untervegs in die Sozialwirtschaft (pp. 21-34). Berlin: edition sigma.

Caritas. (2010). Jahresbericht Retrieved July 4, 2011, from http://www.caritas.de/19729.html

Caritas. (2012). Geschäftsbericht des Deutschen Caritasverbandes e.V. 2011 Retrieved November 21, 2012, from

http://www.caritas.de/diecaritas/deutschercaritasverband/verbandszentrale/transparenz/geschaefts bericht/

Creswell, J. W. (2007). Qualitative Inquiry and Research Design. Choosing among five Approaches (2 ed.). Thousand Oaks: Sage. 
Dahme, H.-J., \& Wohlfahrt, N. (2007). Vom Korporatismus zur strategischen Allianz von Sozialstaat und Sozialwirtschaft: Neue 'Sozialpartnerschaft" auf Kosten der Beschäftigten? In H.-J. Dahme, A. Trube \& N. Wohlfahrt (Eds.), Arbeit in sozialen Diensten: flexibel und schlecht bezablt? (pp. 22-34). Baltmannsweiler.

Deckop, J. R., \& Cirka, C. C. (2000). The Risk and Reward of a Double-Edgedsword: Effects of a Merit Payprogram on Intrinsic Motivation. Nonprofit and Voluntary Sector Quarterly, 29(3), 400-418.

Delaney, J. T., \& Huselid, M. A. (1996). The impact of Human Resource Management Practices on Perceptions of Organizational Performance. Academy of Management Journal, 39(4), 949-969.

Devanna, M. A., Fombrun, C. J., \& Tichy, N. M. (1984). A Framework for Strategic Human Resource Management. In N. M. Tichy, C. J. Fombrun \& M. A. Devanna (Eds.), Strategic Human Resource Management (pp. 33-55). New York: Wiley.

Ducharme, L. J., Knudsen, H. K., \& Roman, P. (2008). Emotional Exhaustion and Turnover Intention in Human Service Occupations: The protective Role of Coworker Support. Sociological Spectrum, 28, 81104.

Eaton, S. C. (2000). Beyond 'unloving care': linking human resource management and patient care quality in nursing homes. International Journal of Human Resource Management, 11(3), 591-616.

EKD. (2002). Soziale Dienste als Chance. Dienste am Menschen aufbauen, Menschen aktivieren, Menschen Arbeit geben Retrieved February, 2013, from http://www.ekd.de/download/ekd_texte_75_text_sozialedienste.pdf

Ewald, V. (1997). Burnout bei Sozialarbeitern - eine qualitative Untersuchung. Unsere Jugend, 49(5), 184-193.

Frank, R. H. (2004). What price the moral high ground?: ethical dilemmas in competitive environments. Princeton, NJ: Princeton University Press.

Frumkin, P., \& Andre-Clark, A. (2000). When missions, markets, and politics collide: Values and strategy in the nonprofit human services. Nonprofit and Voluntary Sector Quarterly, 29, 141-163.

Glaser, B. G., \& Strauss, A. L. (1967). The Discovery of Grounded Theory: Strategies for Qualitative Research. New York: Aldine Press.

Glisson, C., \& Durick, M. (1988). Predictors of Job Satisfaction and Organizational Commitment. Administrative Science Quarterly, 33(1), 61-81.

Göpfert-Divivier, W., \& Ahr, C. (2004). Personalentwicklung und Qualifizierung Retrieved July 24, 2012, from http://www.equal-altenhilfe.de/files/Grundlagen/G_03/G_03.pdf

Guo, C., Brown, W., Ashcraft, R., Yoshioka, C. F., \& Dong, D. (2011). Strategic Human Resource Management in Nonprofit Organizations. Review of Public Personnel Administration, 31(248-269).

Hall, M., Andrukow, A., \& Associates. (2008). The Capacity to serve: A qualitative Study of the Challenges facing Canada's Nonprofit and Voluntary Organizations. Retrieved from

Handy, F., \& Katz, E. (1998). The Wage Differential between Nonprofit Institutions and Corporations: Getting more by paying less? Journal of Comparative Economics, 26(2), 246-261.

Handy, F., Wakaruk, A., Seto, S., Mersey, B., Mejia, A., \& Copeland, L. (2010). The Discerning Consumer: Is Nonprofit Status a Factor in Consumer Choice? Nonprofit and Voluntary Sector Quarterly, 39(5), 866-883.

Hansmann, H. B. (1987). Economic theories of nonprofit organization. In W. W. Powell (Ed.), The nonprofit sector: $A$ research handbook (pp. 27-42). New Haven, CT: Yale University Press.

Hesse, S. (2006). Nutzen von Mitarbeiterjahresgesprächen in einer sozialen Organisation. Das Beispiel des Caritasverbandes Frankfurt am Main. Organisationsberatung - Supervision - Coaching, 4, 377-385.

Hüdepohl, A. (1996). Organisation der Woblfahrtspflege: eine ökonomische Analyse ausgewäblter nationaler und internationaler Institutionen. Berlin: Duncker und Humblot.

Khilji, S. E., \& Wang, X. (2006). 'Intended' and 'implemented' HRM: The missing Linchpin in Strategic Human Resource Management Research. International Journal of Human Resource Management, 17, 11711189.

Knorr, F., \& Scheppach, M. (1998). Leistungsberogene Entgeltsysteme. Für Woblfahrtsverbände und Non-ProfitOrganisationen. Regensburg: Walhalla.

Kuvaas, B. (2008). An exploration of how the employee-organization relationship affects the linkage between perception of developmental human resource practices and employee outcomes. Journal of Management Studies, 45(1), 1-25. 
Lengnick-Hall, M. L., Lengnick-Hall, C., Andrade, L., \& Drake, B. (2009). Strategic Human Resource Management: The Evolution of the Field. Human Resource Management Review, 64-85.

Lepak, D. P., \& Snell, S. A. (1999). The Human Resource Architecture: Toward a Theory of Human Capital Allocation and Development. Academy of Management Review, 24(1), 31-48.

Light, P. C. (2002). The Content of Their Character: The State of the Nonprofit Workforce. Nonprofit Quarterly, 9(3), 6-16.

Macduffie, J. P. (1995). Human Resource Bundles and Manufacturing Performance: Organizational Logic and Flexible Production Systems in the World Auto Industry. Industrial and Labor Relations Review, 48(2), 197-221.

Maelicke, B. (1989). Management in sozialen Organisationen. Blätter der Woblfahrtspflege, 136, 67-70.

Maelicke, B. (2004). Personal als Erfolgsfaktor in der Sozialwirtschaft. Baden-Baden: Nomos.

Marcus, H.-J. (2006). Unterwegs zwischen Scylla und Charybdis - die Caritas zwischen Kirche und Sozialstaatskrise. In H. Manderscheid \& J. Hake (Eds.), Wie viel Caritas braucht die Kirche - wie viel Kirche braucht die Caritas? (pp. 95-106). Stuttgart: Kohlhammer.

Marcus, H.-J. (2008). Erkenntnisse aus dem Umbau und der Modernisierung des Dach- und Spitzenverbandes Caritas - Personalbeteiligung und Personalentwicklung. In V. Brinkmann (Ed.), Personalentwicklung und Personalmanagement in der Sozialwirtschaft (pp. 41-52). Wiesbaden: VS Verlag für Sozialwissenschaften.

Morse, J. (1995). The significance of saturation. Qualitative Health Research, 5(2), 147-149.

Neumann, S. (2004). Personal und Personalmanagement in NPO. Zur Bedeutung des Personals und der Ausgestaltung ihres Managements. . Münsteraner Diskussionspapiere zum Nonprofit-Sektor 25. Retrieved from http://www.aktive-buergerschaft.de/vab/resourcen/diskussionspapiere/wp-band25.pdf

Nishii, L. H., Lepak, D. P., \& Schneider, B. (2008). Employee Attributions of the "why" of HR Practices: Their Effects on Employee Attitudes and Behaviors, and Customer Satisfaction. Personnel Psychology, 61, 503-545.

Oliva, H., Oppl, H., \& Schmid, R. (1991). Rolle und Stellenwert freier Woblfahrtspflege. München.

Ostroff, C. (1992). The Relationship Between Satisfaction, Attitudes, and Performance: An Organizational Level Analysis. Journal of Applied Psychology, 77(6), 963-974.

Patton, M. Q. (1990). Qualitative Evaluations and Research Methods. Newbury Park, CA:: Sage.

Pfeffer, J. (2007). Human Resources from an Organizational Behavior Perspective: Some Paradoxes explained. Journal of Economic Perspectives, 21(4), 115-134.

Ridder, H.-G., Bruns, H.-J., \& Neumann, S. (2004). Nonprofit-Organisationen im Spannungsfeld von normativer und ökonomischer Rationalität - Der Beitrag des Human Resource Management zum Veränderungsmanagement. Zeitschrift für öffentliche und gemeinwirtschaftliche Unternebmen, 27(1), 31-55.

Ridder, H.-G., \& Hoon, C. (2009). Introduction to the Special Issue: Qualitative Methods in Research on Human Resource Management. Zeitschrift für Personalforschung, 23(2), 293-306.

Ridder, H.-G., \& McCandless, A. (2010). Influences on the Architecture of Human Resource Management in Nonprofit Organizations. Nomprofit and Voluntary Sector Quarterly, 29(1), 124-141.

Ridder, H.-G., McCandless Baluch, A., \& Piening, E. P. (2012). The whole is more than the sum of its parts? How HRM is configured in nonprofit organizations and why it matters. Human Resource Management Review, 22, 1-14.

Ridder, H.-G., Piening, E. P., \& McCandless Baluch, A. (2012). The Third Way Reconfigured: How and Why Nonprofit Organizations are Shifting Their Human Resource Management. Voluntas, 23, 605-635.

Rodwell, J. J., \& Teo, S. T. (2004). Strategic HRM in For-Profit and Non-Profit Organizations in a knowledge-intensive Industry. Public Management Review, 6(3), 311-331.

Rodwell, J. J., \& Teo, S. T. (2008). The Influence of Strategic HRM and Sector on perceived Performance in Health Service Organizations. International Journal of Human Resource Management, 19(10), 1825-1841.

Rondeau, K. V., \& Wagar, T. H. (2001). Impact of human resource management practices on nursing home performance. Health Services Management Research, 14, 192-202.

Snell, S. A., \& Dean, J. W. J. (1992). Integrated Manufacturing and Human Resource Management: A Human Capital Perspective. Academy of Management Journal, 35(3), 467-504. 
Strassner, V. (2009). Fübren im Soz̧ialwesen. Eine ethishce Analyse von Mitarbeitergesprächen und Zielvereinbarungen. Freiburg im Breisgau: Lambertus.

Theuvsen, L. (2004). Doing better while doing good: Motivational aspects of pay-for-performance effectiveness in nonprofit organizations. Voluntas, 15(2), 117-136.

Truss, C. (2001). Complexities and controversies in linking HRM with organizational outcomes. Journal of Management Studies, 38(8), 1121-1149.

VdDD. (2013). Tarifpolitische Modernisierung Retrieved February, 2013, from http://www.v3d.de/Tarifpolitische-Modern.19.0.html

Vilain, M. (2002). Nonprofit Management - Current Challenges for Personnel Management in German Welfare Organisations. Paper presented at the ISTR, Cape Town, South Africa. http://c.ymcdn.com/sites/www.istr.org/resource/resmgr/working_papers_cape_town/vilain.pdf

Walk, M., Handy, F., \& Schinnenburg, H. (2013). Expectations and Experiences of Young Employees: The Case of German Nonprofits. Administration in Social Work, 37(2), 133-146.

Weber, M., Herzer, M., Glaser, K., \& Hanke, F. (1995). Führungsfortbildung und Personalentwicklung in der Caritas Köln. Gruppendynamik, 26, 467-487.

Wohlfahrt, N. (2012). Auswirkungen der neuen Steuerungsmodelle auf die Arbeits- und Beschäftigungsmodelle der Sozialen Arbeit. In J. Hagn, P. Hammerschmidt \& J. Sagebiel (Eds.), Modernisierung der Kommunalen Soz̧ialverwaltung - Soziale Arbeit unter Reformdruck (pp. 127-148). München: Schriftenreiche Soziale Arbeit.

Wöhrle, A. (2008). Der zweite Professionalisierungsschub durch Sozialmanagement. In V. Brinkmann (Ed.), Personalentwicklung und Personalmanagement in der Sozialwirtschaft (pp. 13-40). Wiesbaden: VS Verlag für Sozialwissenschaften.

Wright, P. M., Dunford, B. B., \& Snell, S. A. (2001). Human resources and the resource based view of the firm. Journal of Management, 27, 701-721.

Wright, P. M., \& McMahan, G. (1992). Theoretical Perspectives for Strategic Human Resource Management. Journal of Management, 18(2), 295-320.

Zimmer, A., \& Freise, M. (2003). Personalmanagement in Nonprofit-Organisationen. In W. Lange \& U. Hunger (Eds.), Woblfabrtsverbände im Wandel Qualitätsmanagement und Professionalisierung (pp. 107-134). Münster.

Zimmer, A., Gärtner, J., Priller, E., Rawert, P., Sachße, C., Graf Strachwitz, R., \& al., e. (2004). The Legacy of Subsidiarity: The Nonprofit Sector in Germany. In A. Zimmer \& E. Priller (Eds.), Future of Civil Society. Making Central European Nonprofit Organizations work ((pp. 681-711). Wiesbaden: VS Verlag für Sozialwissenschaften.

Zimmer, A., \& Toepler, S. (2000). Government policy and future issues. Federal Republic of Germany. In A. Zimmer (Ed.), The third sector in Germany. Münsteraner Diskussionspapiere zum Nonprofit-Sektor. (pp. 23-79). Münster. 
Table 1: Form of Employment in FWAs

\begin{tabular}{|llll|}
\hline Form & $\begin{array}{l}\text { Full-time / } \\
\text { part-time }\end{array}$ & Duration & $\begin{array}{l}\text { Financed by } \\
\text { (predominantly) }\end{array}$ \\
\hline Employees & $\begin{array}{l}\text { Full-time/ } \\
\text { part-time }\end{array}$ & varying & $\begin{array}{l}\text { FWAs (mainly through } \\
\text { project-related funding) }\end{array}$ \\
\hline Apprentices & Full-time & 2 to 3 years & FWAs \\
\hline Job Creation Measures & Full-time & 12 months & $\begin{array}{l}\text { Federal Employment } \\
\text { Agency }\end{array}$ \\
\hline $\begin{array}{l}\text { Community Service (until } \\
\text { June 2011) }\end{array}$ & Full-time & 9 months & Federal Ministry \\
\hline Voluntary Social Year & Full-time & $\begin{array}{l}6 \text { to } 12 \\
\text { months }\end{array}$ & Federal Ministry \\
\hline Integration Measures & Full-time & varying & $\begin{array}{l}\text { FWAs and Social Affairs } \\
\text { Department }\end{array}$ \\
\hline Volunteers & $\begin{array}{l}\text { Several } \\
\text { hours/part- } \\
\text { time }\end{array}$ & varying & unpaid \\
\hline Board members & $\begin{array}{l}\text { Several } \\
\text { hours/part- } \\
\text { time }\end{array}$ & varying & unpaid \\
\hline
\end{tabular}

Source: Authors' table following Vilain (2002). 


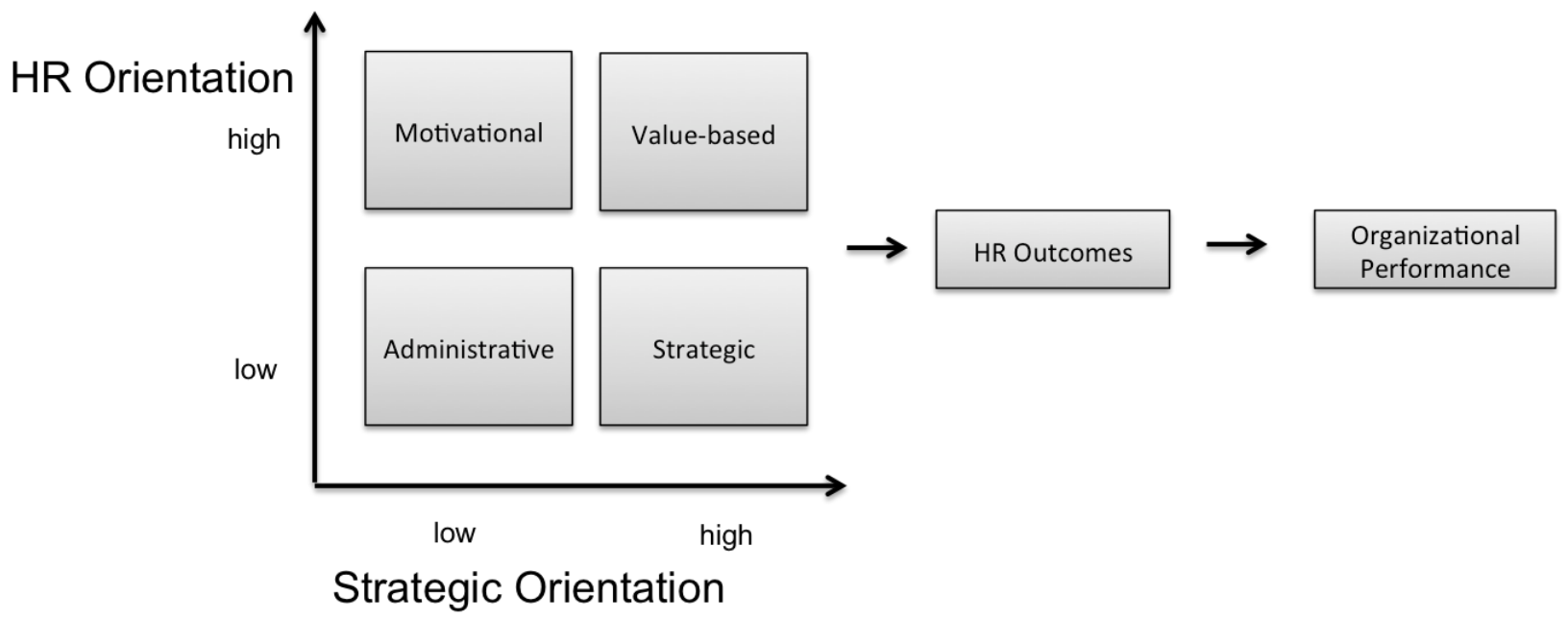

Figure 1: Following Ridder and colleagues (2010, 2012).

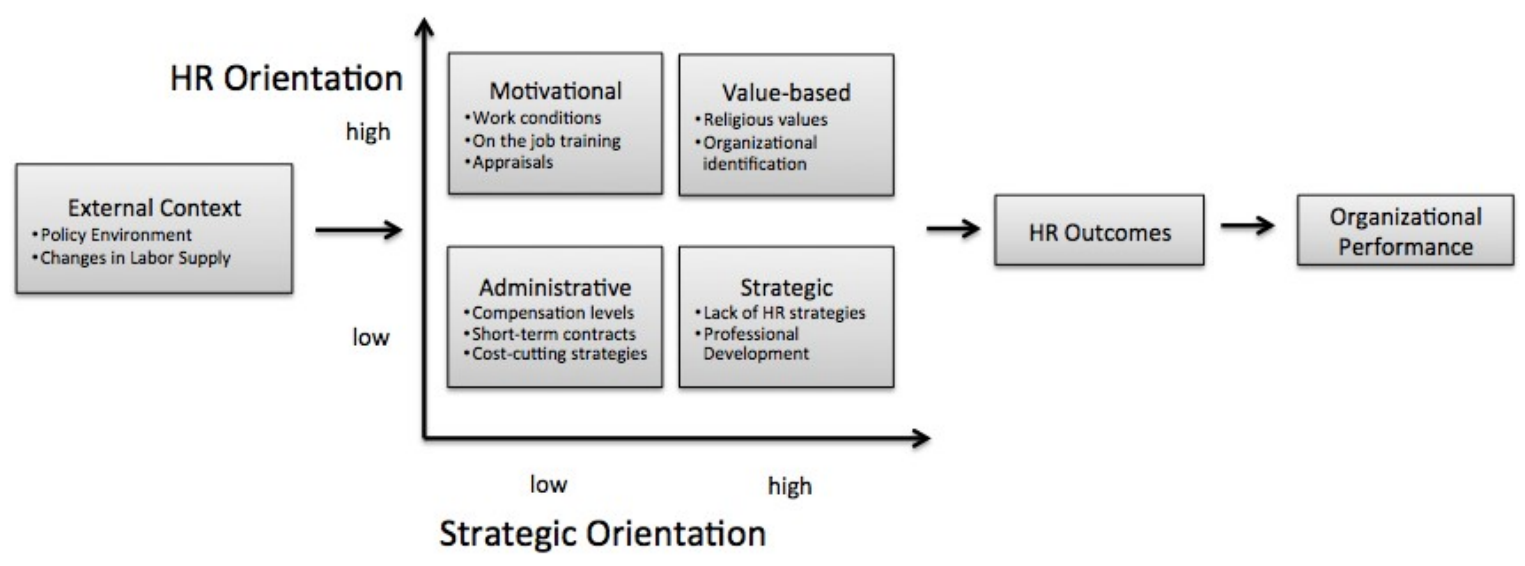

Figure 2: Authors' own figure. 